\title{
ANALISIS CVP SEBAGAI ALAT PENGAMBILAN KEPUTUSAN MANAJEMEN TERHADAP PRODUCT COST
}

\author{
Nur Atiqah \\ Institut Agama Islam Negeri Pontianak \\ email : nur_atiqah@iainptk.ac.id
}

\begin{abstract}
ABSTRAK
Analisis CVP (Cost-Volume-Profit) dengan mengetahui hubungan, perkiraan dan perhitungan atas biaya, volume, laba dan harga jual, memungkinkan pengambilan keputusan yang baik terhadap manajemen serta product cost. Dalam pengambilan keputusan jangka pendek diperlukan perhitungan CVP agar anggaran atau target laba yang dikehendaki dapat ditentukan. Sehingga tujuan dari penelitian ini adalah untuk menganalisis analisis CVP terhadap perubahan harga jual per unit, volume penjualan, biaya variabel per unit dan biaya tetap produk. Penelitian dilakukan dengan pendekatan literature review. Hasil penelitian ini yaitu (1) perhitungan CVP terhadap perubahan harga jual per unit produk pada kondisi biaya tetap, biaya variabel, volume penjualan bersifat konstan atau tidak berubah terlihat kenaikan persentase harga jual yang mengakibatkan persentase kenaikan laba, dan ketika perusahaan ingin menaikkan harga jual dengan laba yang dikehendaki adalah tetap, maka akan terjadi perubahan volume penjualan, (2) perhitungan CVP terhadap perubahan volume penjualan produk pada kondisi harga jual produk, biaya tetap, biaya variabel, bersifat konstan menghasilkan kenaikan volume penjualan yang menyebabkan kenaikan total biaya produk. (3) perhitungan CVP terhadap perubahan biaya variabel per unit produk pada kondisi harga jual produk, biaya tetap, dan volume penjualan, bersifat konstan atau tetap terlihat bahwa kenaikan biaya variabel produk menyebabkan penurunan laba. (4) perhitungan CVP terhadap perubahan total biaya tetap produk pada kondisi harga jual produk, biaya variabel per unit produk, dan volume penjualan, bersifat tetap atau konstan, menghasilkan kenaikan biaya tetap
\end{abstract}


produk yang diikuti kenaikan total biaya produk yang kemudian menyebabkan penurunan laba.

Keywords : CVP, Product Cost 


\section{PENDAHULUAN}

Perusahaan yang melakukan kegiatan operasional memproduksi barang atau jasa, tidak terlepas dari perhitungan biaya. Berbagai metode digunakan untuk melakukan perhitungan biaya atau yang disebut dengan product costing. Product costing dilakukan dengan memisahkan antara biaya tetap dan biaya variabel. Pemisahan antara biaya tetap dan biaya variabel ditujukan agar dapat mengetahui batas kontribusi yang berguna untuk menentukan rencana besarnya laba serta memudahkan dalam pengendalian kondisi operasional perusahaan.

Di pasar global yang bergerak dengan cepat dan dengan sumber daya yang terbatas, perusahaan dapat menggunakan analisis margin kontribusi dan CVP (Enyi, 2019). Besar kecilnya laba dapat dikatakan sebagai tolak ukur keberhasilan perusahaan. Keberhasilan perusahaan profit-oriented dapat dilihat dari jumlah laba yang diperoleh. Laba yang dikehendaki dapat ditentukan oleh perusahaan dengan perencanaan atau penganggaran laba. Ada tiga faktor yang mempengaruhi laba perusahaan yaitu biaya, harga jual, serta volume penjualan dan produksi. Biaya untuk pengolahan suatu produk atau jasa akan mempengaruhi besarnya volume pernjulan produk atau jasa yang bersangkutan, sedangkan besarnya volume penjualan berpengaruh terhadap volume produksi produk atau jasa. Selanjutnya volume produksi akan mempengaruhi besar kecilnya biaya produksi (Halim dkk, 2013).

Berdasarkan latar belakang yang telah dikemukakan, maka tujuan dari penelitian ini antara lain untuk menganalisis CVP terhadap perubahan harga jual per unit produk, CVP terhadap perubahan volume penjualan produk, CVP terhadap perubahan biaya variabel per unit produk, serta CVP terhadap perubahan total biaya tetap produk.

\section{KAJIAN PUSTAKA}

\section{CVP (Cost-Volume-Profit)}

Analisis Cost-Volume-Profit (CVP) merupakan suatu alat yang sangat berguna untuk perencanaan dan pengambilan keputusan. Oleh karena analisis CVP menekankan keterkaitan antara biaya, kuantitas yang terjual, dan harga maka semua informasi keuangan perusahaan terkandung didalamnya. Analisis CVP dapat menjadi suatu alat yang bermanfaat untuk mengidentifikasi cakupan dan besarnya kesulitan ekonomi yang 
dihadapi suatu divisi dan membantu mencari pemecahannya. Keputusan awal perusahaan dalam mengimplementasikan pendekatan unit yang terjual pada analisis CVP adalah menentukan apa yang dimaksud dengan sebuah unit. Analisis CVP memfokuskan pada berbagai faktor yang mempengaruhi perubahan dalam komponen laba. (Hansen, Don $\mathrm{R}$ dan Maryanne M. Mowen, 2018).

Penerapan analisis CVP untuk pengambilan keputusan manajemen (Zaroni, 2017) adalah untuk menentukan unit yang harus dijual dan jumlah penjualan minimal agar perusahaan tidak rugi atau profit sama dengan nol, menentukan unit yang harus dijual atau berapa jumlah penjualan agar perusahaan mencapai target laba operasi (operating income) yang diinginkan, memilih alternatif skenario kebijakan iklan, otomasi mesin pabrik, menaikkan harga jual produk atau jasa, dan lain-lain, dengan pilihan skenario yang dapat memberikan profit maksimal, menganalisis sensitivitas atas risiko ketidakpastian harga jual, biaya, dan market serta menganalisis margin of safety dan leverage.

Asumsi penggunaan analisis CVP (Kamaruddin, 2017):

a. Konsep tentang variablitias cost dapat diterima karena itu biaya harus realistis diklasifikasikan sebagai variabel dan tetap

b. Range yang relevan pada semua tahap analisis harus ditentukan

c. Harga jual per unit tidak berubah jika terjadi perubahan volume

d. Hanya dijual satu jenis produk (single product)

e. Jika analisis digunakan untuk berbagai produk atau kombinasi produk (product mix) sales mix harus tetap atau konstan

f. Kebijaksanaan manajemen terhadap operasi perusahaan tidak berubah secara material dalam jangka pendek

g. Tingkat harga umum stabil dalam jangka pendek

h. Sinkronisasi antara penjualan dan produksi yang berarti tingkatan persediaan harus konstan atau nol

i. Efisiensi dan produktivitas tidak mengalami perubahan-perubahan khususnya dalam jangka pendek 


\section{Product Cost}

Biaya produk sering didefinisikan sebagai biaya produksi yaitu jumlah dari bahan baku langsung, tenaga kerja langsung, dan overhead produksi. Definisi product cost tersebut diharuskan untuk pelaporan keuangan pihak eksternal sehingga memainkan peranan penting dalam penilaian persediaan dan menentukan pendapatan (Hansen, 2018). Sistem akuntansi manajerial dan akuntansi biaya membebankan dan mengukur biaya agar biaya per unit produk dapat dihitung. Penawaran yang dilakukan harus disertai dengan pengetahuan manajemen mengenai biaya produk per unit.

Biaya perlu diklasifikasikan untuk menentukan metode yang tepat dalam menghimpun dan mengalokasikan biaya (Ahmad, 2017). Metode klasifikasi yang penting dapat dijelaskan sebagai berikut:

a. Saat Dibebankan ke Pendapatan

1) Biaya produk: biaya-biaya yang dimasukkan pada waktu penghitungan biaya produksi. Biaya produk termasuk dalam persedian dan dan dalam harga pokok penjualan apabila produk dijual.

2) Biaya periode: biaya yang berkaitan dengan perjalanan waktu dan bukan dengan jumlah produk. Biaya ini ditunjukkan pada biaya perhitungan laba/rugi setiap akhir periode karena tidak ada lagi manfaat yang diterima di masa mendatang.

b. Kaitannya dengan Volume

1) Variabel: yaitu biaya yang jumlahnya berubah secara proporsional dengan perubahan kegiatan bersangkutan. Biaya satuan tidak berubah dan tidak dipengaruhi oleh volume.

2) Tetap: biaya yang tidak berubah jumlahnya sekalipun volume berubah. Harga satuannya akan turun bila volumenya meningkat.

Analisis sumber daya dari berbagai informasi yang terperinci membuat perhitungan menjadi aspek operasional rutin. Data mengenai biaya produk juga merupakan umpan balik bagi pengambil keputusan manajemen. Bahkan dalam bisnis tertentu, praktek penetapan biaya produk digunakan untuk mengetahui biaya yang terkait dengan identifikasi fungsi- fungsi penting dari produksi. 


\section{METODOLOGI}

Penelitian ini menggunakan pendekatan literature review. Telaah pustaka (literature review) adalah bagian dari proses penelitian yang memberikan pandangan dan arahan dalam sebuah rangkaian penelitian ilmiah. Pada dasarnya telaah pustaka dibutuhkan sejak pertama kali penulis merencanakan akan membuat penelitian. . Penulis diarahkan pada menghasilkan "contribution to the body of knowledge". Sebuah studi pustaka yang baik akan menghasilkan dasar bagi pengembangan teoritis yang komprehensif (Ferdinand, 2014).

Ditinjau dari segi tujuan, penelitian ini menggunakan model deskriptif. Model deskriptif ditujukan untuk menjabarkan atau mendeskripsikan sebuah situasi atau serangkaian proses (Ferdinand, 2014). Olah data yang dihasilkan diuraikan secara teratur kemudian diberikan penjelasan serta pemahaman agar dapat dipahami dengan baik oleh pembaca.

\section{HASIL DAN PEMBAHASAN}

\section{Analisis CVP terhadap Perubahan Harga Jual Per Unit Produk}

Perubahan harga jual produk pada analisis CVP berpengaruh langsung terhadap penerimaan pendapatan usaha. Total revenue merupakan unsur yang membentuk titik impas. Penurunan harga jual per unit akan menaikkan titik impas penjualan, sedangkan kenaikan harga jual per unit akan menurunkan titik impas. Agar dapat mencapai laba usaha yang ditetapkan, biaya tetap per unit berubah diikuti perubahan harga jual per unit. Pada analisis CVP ini, perubahan harga jual per unit produk akan mempengaruhi volume penjualan dan laba perusahaan, dapat dilihat pada tabel 4.1.

Tabel 4.1

CVP terhadap Perubahan Harga Jual Per Unit Produk

\begin{tabular}{|c|c|c|c|c|c|}
\hline $\begin{array}{c}\text { Harga Jual } \\
\text { Awal }\end{array}$ & $\begin{array}{c}\text { Perubahan } \\
\text { Harga Jual }\end{array}$ & Laba Awal & $\begin{array}{c}\text { Perubahan } \\
\text { Laba }\end{array}$ & $\begin{array}{c}\text { Persentase Perubahan } \\
\text { Harga Jual }\end{array}$ & $\begin{array}{c}\text { Persentase } \\
\text { Perubaha Laba }\end{array}$ \\
\hline $\mathrm{Rp} \mathrm{5.000}$ & $\mathrm{Rp} \mathrm{5.500}$ & $\mathrm{Rp} 600.000$ & $\mathrm{Rp} 650.000$ & $10 \%$ & $8 \%$ \\
\hline $\mathrm{Rp} 5.000$ & $\mathrm{Rp} 6.000$ & $\mathrm{Rp} 600.000$ & $\mathrm{Rp} 750.000$ & $20 \%$ & $25 \%$ \\
\hline $\mathrm{Rp} 5.000$ & $\mathrm{Rp} 6.500$ & $\mathrm{Rp} 600.000$ & $\mathrm{Rp} 850.000$ & $30 \%$ & $42 \%$ \\
\hline
\end{tabular}

Sumber: Hasil Olah Data, 2019

Tabel diatas dihitung dengan kondisi biay a tetap, biaya variabel, volume penjualan bersifat konstan, yaitu jika biaya tetap sebesar Rp 50.000, biaya variabel sebesar Rp 
2.000, serta volume penjualan sebanyak 200 unit. Perubahan persentase harga jual $10 \%$ mengakibatkan perubahan persentase laba sebesar $8 \%$, perubahan persentase harga jual $20 \%$ mengakibatkan perubahan persentase laba sebesar $25 \%$, dan perubahan persentase harga jual $20 \%$ mengakibatkan perubahan persentase laba sebesar $42 \%$. Jadi pada kondisi tersebut, kenaikan persentase harga jual mengakibatkan persentase kenaikan laba.

Ketika perusahaan ingin menaikkan harga jual dengan laba yang dikehendaki adalah tetap, maka akan terjadi perubahan volume penjualan seperti yang terlihat pada tabel 4.2.

Tabel 4.2

CVP terhadap Perubahan Harga Jual Per Unit Produk dan Volume Penjualan

\begin{tabular}{|c|c|c|c|c|}
\hline $\begin{array}{l}\text { Laba Awal Yang } \\
\text { Dikehendaki }\end{array}$ & Harga Jual & Biaya Tetap & $\begin{array}{c}\text { Biaya } \\
\text { Variabel }\end{array}$ & $\begin{array}{c}\text { Perubahan Volume } \\
\text { Penjualan }\end{array}$ \\
\hline $\begin{array}{ll}\mathrm{Rp} & 600.000 \\
\end{array}$ & 5.500 & Rp 50.000 & $\operatorname{Rp} 2.000$ & 186 unit \\
\hline $\begin{array}{ll}\mathrm{Rp} & 600.000 \\
\end{array}$ & 6.000 & Rp 50.000 & Rp 2.000 & 163 unit \\
\hline $\begin{array}{ll}\mathrm{Rp} & 600.000 \\
\end{array}$ & $\mathrm{Rp} \quad 6.500$ & Rp 50.000 & $\mathrm{Rp} 2.000$ & 144 unit \\
\hline
\end{tabular}

Sumber: Hasil Olah Data, 2019

Tabel 4.2 dihitung dengan kondisi laba awal yang dikendaki, biaya tetap, dan biaya variabel bersifat konstan, yaitu jika laba awal yang dikendaki sebesar Rp600.000, biaya tetap sebesar Rp50.000, dan biaya variabel sebesar Rp2.000. Ketika harga jual berubah sedangkan laba yang dikendaki tetap, maka terjadi perubahan volume penjualan dari 200 unit berkurang menjadi 186 unit untuk harga jual Rp5.500, 163 unit untuk harga jual Rp6.000, dan 144 unit untuk harga jual Rp6.500. Jadi, untuk laba yang sama atau tetap, kenaikan harga jual mengakibatkan penurunan volume penjualan.

\section{Analisis CVP terhadap Perubahan Volume Penjualan Produk}

Perubahan volume penjualan berpengaruh terhadap laba usaha dan total biaya. Jika volume produksi yang melebihi kapasitas produksi maka biaya yang dikeluarkan akan semakin besar dan menimbulkan kerugian bagi entitas bisnis. Pada analisis CVP ini, perubahan volume penjualan produk akan mempengaruhi tingkat laba perusahaan, dapat dilihat pada tabel 4.3. 
Tabel 4.3

CVP terhadap Perubahan Volume Penjualan Produk

\begin{tabular}{|c|c|c|c|c|c|c|}
\hline $\begin{array}{l}\text { Perubahan } \\
\text { Volume } \\
\text { Penjualan }\end{array}$ & $\begin{array}{c}\text { Total Biaya } \\
\text { Awal }\end{array}$ & $\begin{array}{l}\text { Perubahan } \\
\text { Total Biaya }\end{array}$ & $\begin{array}{l}\text { Persentase } \\
\text { Perubahan } \\
\text { Total Biaya }\end{array}$ & Laba Awal & $\begin{array}{c}\text { Perubahan } \\
\text { Laba }\end{array}$ & $\begin{array}{c}\text { Persentase } \\
\text { Perubahan } \\
\text { Laba }\end{array}$ \\
\hline & & & & & & $5 \%$ \\
\hline 220 unit & $\operatorname{Rp} 450,000$ & $\operatorname{Rp} 490,000$ & $9 \%$ & $\operatorname{Rp} 600,000$ & Rp 660,000 & $10 \%$ \\
\hline 250 unit & $\operatorname{Rp} 450,000$ & $\operatorname{Rp} 550,000$ & $22 \%$ & $\operatorname{Rp} 600,000$ & $\operatorname{Rp} 750,000$ & $25 \%$ \\
\hline
\end{tabular}

Sumber: Hasil Olah Data, 2019

Tabel 4.3 dihitung dengan kondisi harga jual produk, biaya tetap, biaya variabel, bersifat konstan, yaitu jika harga jual per unit produk sebesar Rp5.000, biaya tetap sebesar Rp50.000, dan biaya variabel sebesar Rp2.000. Perubahan persentase total biaya produk sebesar 4\% yang diakibatkan oleh perubahan volume penjualan dari 200 unit menjadi 210 unit menyebabkan perubahan persentase laba sebesar 5\%, perubahan persentase total biaya produk yang diakibatkan oleh perubahan volume penjualan dari 200 unit menjadi 220 unit sebesar 9\% menyebabkan perubahan persentase laba sebesar $10 \%$, dan perubahan persentase total biaya produk $22 \%$ yang diakibatkan oleh perubahan volume penjualan dari 200 unit menjadi 250 unit menyebabkan perubahan persentase laba sebesar $42 \%$. Jadi pada kondisi tersebut, kenaikan volume penjualan menyebabkan kenaikan total biaya produk.

\section{Analisis CVP terhadap Perubahan Biaya Variabel Per Unit Produk}

Perubahan biaya variabel per unit akan berpengaruh terhad ap laba usaha dan total biaya. Perubahan biaya variabel per unit produk juga akan mempengaruhi margin kontribusi dan titik impas. Penurunan biay a variabel per unit akan menaikkan titik impas, begitupula sebaliknya. Pada analisis CVP ini, perubahan variabel per unit produk akan mempengaruhi total biaya dan laba perusahaan, dapat dilihat pada tabel 4.4 
Tabel 4.4

CVP terhadap Perubahan Biaya Variabel Per Unit Produk

\begin{tabular}{|c|c|c|c|c|c|}
\hline $\begin{array}{c}\text { Biaya } \\
\text { Variabel } \\
\text { Awal }\end{array}$ & $\begin{array}{c}\text { Perubahan } \\
\text { Biaya } \\
\text { Variabel }\end{array}$ & Total Biaya & $\begin{array}{c}\text { Perubahan } \\
\text { Total Biaya }\end{array}$ & Laba & $\begin{array}{c}\text { Perubahan } \\
\text { Laba }\end{array}$ \\
\hline Rp 2.000 & $\operatorname{Rp} 2.500$ & $\operatorname{Rp~450.000~}$ & $\operatorname{Rp~550.000~}$ & $\operatorname{Rp~550.000~}$ & $\operatorname{Rp~450.000~}$ \\
\hline $\operatorname{Rp} 2.000$ & $\operatorname{Rp~3.000~}$ & $\operatorname{Rp~450.000~}$ & $\operatorname{Rp~650.000~}$ & $\operatorname{Rp~550.000~}$ & $\operatorname{Rp~350.000~}$ \\
\hline $\operatorname{Rp} 2.000$ & $\operatorname{Rp~3.500~}$ & $\operatorname{Rp~450.000~}$ & $\operatorname{Rp~750.000~}$ & $\operatorname{Rp~550.000~}$ & $\operatorname{Rp~250.000~}$ \\
\hline
\end{tabular}

Sumber: Hasil Olah Data, 2019

Tabel 4.4 dihitung dengan kondisi harga jual produk, biaya tetap, dan volume penjualan, bersifat konstan atau tetap, yaitu jika harga jual per unit produk sebesar Rp5.000, biaya tetap sebesar Rp50.000, dan volume penjualan sebanyak 200 unit. Kenaikan biaya variabel produk dari Rp2.000 menjadi Rp2.500 diikuti dengan kenaikan total biaya produk dari Rp450.000 menjadi Rp550.000 menyebabkan penurunan laba dari Rp550.000 menjadi Rp450.000, kenaikan biaya variabel produk dari Rp2.000 menjadi Rp3.000 diikuti dengan kenaikan total biaya produk dari Rp450.000 menjadi Rp650.000 menyebabkan penurunan laba dari Rp550.000 menjadi Rp350.000, kenaikan biaya variabel produk dari Rp2.000 menjadi Rp3.000 diikuti dengan kenaikan total biaya produk dari Rp450.000 menjadi Rp750.000 menyebabkan penurunan laba dari Rp550.000 menjadi Rp250.000. Jadi pada kondisi tersebut, kenaikan biaya variabel produk menyebabkan penurunan laba. Hal ini juga mengakibatkan berubahnya titik impas yang semula Rp83.333 menjadi Rp100.000 pada biaya variabel Rp2.500, titik impas dari Rp83.333 menjadi Rp125.000 pada biaya variabel Rp3.000, dan titik impas dari Rp83.333 menjadi Rp166.667 pada biaya variabel Rp3.500.

\section{Analisis CVP terhadap Perubahan Total Biaya Tetap Produk}

Setiap penurunan dan kenaikan total biaya tetap akan menentukan volume penjualan yang sesuai untuk mencapai laba yang dikehendaki. Pada analisis CVP ini, perubahan total biaya tetap produk akan mempengaruhi total biaya dan laba perusahaan, dapat dilihat pada tabel 4.5. 
Tabel 4.5

CVP terhadap Perubahan Total Biaya Tetap Produk

\begin{tabular}{|c|c|c|c|c|c|c|}
\hline $\begin{array}{c}\text { Biaya } \\
\text { Tetap }\end{array}$ & $\begin{array}{c}\text { Perubahan } \\
\text { Biaya } \\
\text { Tetap }\end{array}$ & $\begin{array}{c}\text { Biaya } \\
\text { Variabel }\end{array}$ & Total Biaya & $\begin{array}{c}\text { Perubahan } \\
\text { Total Biaya }\end{array}$ & Laba & $\begin{array}{c}\text { Perubahan } \\
\text { Laba }\end{array}$ \\
\hline $\mathrm{Rp} 50.000$ & $\mathrm{Rp} 60.000$ & $\mathrm{Rp} 2.000$ & $\mathrm{Rp} 450.000$ & $\mathrm{Rp} 460.000$ & $\mathrm{Rp} 550.000$ & $\mathrm{Rp} 540.000$ \\
\hline $\mathrm{Rp} 50.000$ & $\mathrm{Rp} 70.000$ & $\mathrm{Rp} 2.000$ & $\mathrm{Rp} 450.000$ & $\mathrm{Rp} 470.000$ & $\mathrm{Rp} 550.000$ & $\mathrm{Rp530.000}$ \\
\hline $\mathrm{Rp} 50.000$ & $\mathrm{Rp} 80.000$ & $\mathrm{Rp} 2.000$ & $\mathrm{Rp} 450.000$ & $\mathrm{Rp} 480.000$ & $\mathrm{Rp} 550.000$ & $\mathrm{Rp} 520.000$ \\
\hline
\end{tabular}

Sumber: Hasil Olah Data, 2019

Tabel 4.5 dihitung dengan kondisi harga jual produk, biaya variabel per unit produk, dan volume penjualan, bersifat tetap atau konstan, yaitu jika harga jual per unit produk sebesar Rp5.000, biaya variabel per unit produk sebesar Rp2.000, dan volume penjualan sebanyak 200 unit. Kenaikan biaya tetap produk dari Rp50.000 menjadi Rp60.000 diikuti dengan kenaikan total biaya produk dari Rp450.000 menjadi Rp460.000 menyebabkan penurunan laba dari Rp550.000 menjadi Rp540.000, kenaikan biaya tetap produk dari Rp50.000 menjadi Rp70.000 diikuti dengan kenaikan total biaya produk dari Rp450.000 menjadi Rp470.000 menyebabkan penurunan laba dari Rp550.000 menjadi Rp530.000, kenaikan biaya tetap produk dari Rp50.000 menjadi Rp80.000 diikuti dengan kenaikan total biaya produk dari Rp450.000 menjadi Rp480.000 menyebabkan penurunan laba dari Rp550.000 menjadi Rp520.000. Jadi pada kondisi tersebut, kenaikan biaya kenaikan biaya tetap produk yang diikuti kenaikan total biaya produk menyebabkan penurunan laba.

\section{KESIMPULAN}

Perhitungan CVP terhadap perubahan harga jual per unit produk pada kondisi biaya tetap, biaya variabel, volume penjualan bersifat konstan atau tidak berubah terlihat kenaikan persentase harga jual yang mengakibatkan persentase kenaikan laba, dan ketika perusahaan ingin menaikkan harga jual dengan laba yang dikehendaki adalah tetap, maka akan terjadi perubahan volume penjualan. Perhitungan CVP terhadap perubahan volume penjualan produk pada kondisi harga jual produk, biaya tetap, biaya variabel, bersifat konstan menghasilkan kenaikan volume penjualan yang menyebabkan kenaikan total biaya produk. Perhitungan CVP terhad ap perubahan biaya variabel per unit produk pada kondisi harga jual produk, biaya tetap, dan volume penjualan, bersifat konstan atau tetap 
terlihat bahwa kenaikan biaya variabel produk menyebabkan penurunan laba. Sedangkan, perhitungan CVP terhadap perubahan total biaya tetap produk pada kondisi harga jual produk, biaya variabel per unit produk, dan volume penjualan, bersifat tetap atau konstan, menghasilkan kenaikan biaya tetap produk yang diikuti kenaikan total biaya produk yang kemudian menyebabkan penurunan laba.

\section{DAFTAR PUSTAKA}

Abdullahi, Sadiq Rabiu dkk. 2017. Cost-Volume-Profit Analysis as a Management Tool for Decision Making in Small Business Enterprise within Bayero University Kano. Iosr Jurnal of Business and Management 19 (2), 40-45.

Ahmad, Kamaruddin. 2017. Akuntansi Manajemen: Dasar-dasar Konsep Biaya dan Pengambilan Keputusan. Rajawali Pers, Jakarta.

Ali, Md dan Syed Moudud U1 Huq. 2016. Textile Industry in Bangladesh: An Analysis of CVP. Management Studies and Economic Systems 54 (4144), 1-12.

Choo, Freddie dan Kim B. Tan. 2011. An Income Statement Teaching Approach for Cost-Volume-Profit (CVP) Analysis by Using a Company's CVP Model. Journal of accounting and Finance 11 (4), 23.

Dash, Mihir. 2019. Exploring the Applicability of the CVP Model in the Indian Cement sector. Asian Journal of Pure an Applied Mathematics, 8-15.

Enyi, Enyi Patrrick. 2019. Joint Product CVP Analysis-Time for Methodical Review. Journal of Economic and Business 2 (4), 1288-1297.

Ferdinand, Augusty. 2014. Metode Penelitian Manajemen: Pedoman Penelitian Untuk Penulisan Skripsi, Tesis, dan Disertasi Ilmu Manajemen. Badan Penerbit Undip, Semarang.

Guidry, Flora dkk. 1998. CVP analysis: A New Look. Journal of managerial Issues 10 (1), 74-85.

Halim, Abdul dkk. 2013. Akuntansi Manajemen (Akuntansi Manajerial). BPFE, Yogyakarta.

Hansen, Don R dan Maryanne M. Mowen. 2015. Akuntansi Manajemen. Salemba Empat, Jakarta. 
Hansen, Don R dan Maryanne M. Mowen. 2018. Akuntansi Manajerial. Salemba Empat, Jakarta.

Iswara, Ufah Setia dan Susanti. 2017. Analisis Cost Volume Profit sebagai Dasar Perencanaan Laba yang Diharapkan (Studi Pada Perusahaan Kopi di Kabupaten Jember). Jurnal Riset Akuntansi Keuangan 2 (3).

Jiang, Yan dan Zhirong Shen. 2017. Study on the Application of CVP Analysis in Catering Industry. International Conference on Contemporary Education, Social Sciences and Humanities.

Jonny. 2012. Analisis Kelayakan Investasi Perluasan Pabrik dengan Metode CostVolume Profit dan Incremental pada PT XYZ Jakarta. ComTech: Computer, Mathematics and Engineering Applications 3 (1), 524-532.

Kembi, Luke David dkk. 2014. Perencanaan Laba Berdasarkan Analisis Biaya, Volume, Laba pada PT. Multi Food Manado. Jurnal EMBA 2 (4), 354-362.

Said, Hassan A. 2016. Using Different Probability Distributions for Managerial Accounting Technique: The Cost-Volume-Profit Analysis. ASBBS Proceedings 24 (1), 313.

Saputra, Guntur Agus dan Hery Purnomo. 2018. Optimasi Profitabilitas dengan Analisis CVP (Studi: UD Buah Segar "Nur" Ponorogo. Seminar Nasional Manajemen Ekonomi Akuntansi (Senme) 2018.

Yunker, James A dan Penelope J. Yunker. 2003. Stochastic CVP Analysis as Gateway to Decision-Making Under Unvertainty. Journal of Accounting Education 21 (4), 339- 365.

Zaroni, 2017. Analisis Cost Volume Profit (CVP). Website: https://supplychainindonesia.com/new/analisis-cost-volume-profit-cvp. 